\title{
International Classification of Diseases for Oncology (ICD-O) Coding System, Language for Oncology Implications and Update at Orthopaedic Oncology
}

\author{
(1) Mehmet Şerefettin CANDA, ${ }^{1}$ (1) Osman Nuri EROĞLU, ${ }^{2}$ (i) Onur HAPA ${ }^{2}$ \\ 'Department of Pathology, Dokuz Eylül University Faculty of Medicine, Izmir-Turkey \\ ${ }^{2}$ Department of Orthopedics and Traumatology, Dokuz Eylül University Faculty of Medicine, İzmir-Turkey
}

\begin{abstract}
SUMMARY
The International Classification of Diseases for Oncology (ICD-O), created by the World Health Organisation (WHO), is used as a common language among clinicians and researchers. It is regularly updated depending on most recent studies; new codes are added or older ones are revised due to our better understanding of tumour biology and genetics. This review gives a brief explanation and updates of the International Classification of Diseases for Oncology (ICD-O), especially for the orthopaedic codes, at the most recent $3^{\text {rd }}$ edition and $3^{\text {rd }}$ edition first revision of ICD-O and Turkish version of ICD-O.

Keywords: Genetics; ICD-O; international statistical classification; oncology; orthopaedic codes; tumour biology; Turkish version of ICD-O.

Copyright $\odot$ 2021, Turkish Society for Radiation Oncology
\end{abstract}

\section{Introduction}

The International Classification of Diseases for Oncology (ICD-O), created by the World Health Organisation (WHO), has been used for a very long time as a standard tool for coding the site and the histology of the diagnostic terms of the neoplasms in tumour registrars worldwide. [1-4]

The first step at clinical oncology is taking biopsy specimen from the tumour then sending it to the pathology department for histologic diagnosis. Pathological diagnosis is the most important step in clinical oncology, orienting the treatment and prognosis of the patient. This diagnosis must firstly be reliable and scientific; secondly, it must be reported in a language that can be understood worldwide. This coding system is updated regularly as it is dependent on the new information gathered from scientific developments, especially the genetic studies, so enhancing the re- liability of pathology diagnostics from accredited pathology departments. This coding system firstly enables us to make a correct diagnosis, prognosis because of regular updates on both cancer terms and biological behaviour of tumours, and secondly gives us the chance to report it at a common language 'coding system' recognized worldwide. This helps clinicians to adopt uniform terminology so facilitating their communication with each other.[1-4]

Dr. Canda has been working on the Turkish version of ICD-O for the last three decades,[5-7] having simultaneously prepared the Turkish versions of ICD-O 2, ICD-O 3 and ICD-O 3.1, which have been used in Turkey since 1993.[8-10] ICD-O 2 was released by WHO at 1990, the Turkish version was then prepared at 1992, ICD-O 3 was released in 2000, and Turkish version was created subsequently at 2002. ICD-O 3.1 was released in 2013, and the Turkish version followed it in 2018. The most recent version released by WHO is ICD-O3.1 (2013). [8-10] 
The coding usage has been made obligatory by WHO since 1976. Besides public health, especially in the fight against cancer in Turkey, its purpose was to get scientific and social benefit in the field of cancer registry, and its use was made mandatory by the Turkey Ministry of Health in 2015, in all hospitals, healthcare facilities and university hospitals within Turkey.[10] This common language for cancer registry which was used for a very long time in developed countries, if implemented properly in our country, will let us gain cancer statistics across our country and secondarily will enable us to develop future health politics depending on our scientific data, instead of foreign statistics or studies.

\section{ICD-O Third Edition First Revision Definition}

International Classification of Diseases for Oncology (ICD-O) third edition first revision has been created by WHO in 2013. Many revisions have been made at this most recent edition, especially for the morphologic codes of the tumours. It is a classification of tumours consisting of a coding system that includes 10 digits, which consist of the topography section (4 digits) and the morphology section (6 digits; ' 4 digits; cell type' 'histology', 1 digit; biologic behaviour, 1 digit; differentiation or degree of neoplasm). $[4,10]$

ICD-O consists of three sections, Topography index, Morphology index and an alphabetic index.

Topography code gives the origin of the tumour, while morphology code gives the biological activity of the tumour.

Topography code includes four character code between C00.0-C80.9 (C 'site.'subsite').

Example C40. 2 hand. carpal bone.

Morphology code is a code number that is between $8000 / 0$ and $9989 / 1$, consisting of six digits. The first four digits describe the tumor cell type, the fifth digit after the slash describes the biologic behaviour codes (/0 benign, / 1 unknown, / 2 In situ, / 3 malign, /4 metastasis, $/ 9$ malign primary or metastatic unknown).

A separate last digit describes the degree of the histologic differentiation ( 1 well, 2 moderate, 3 less, 4 none, 9 not defined). [1-4,8-10]

M- ----(cell type)/-(behaviour)-(differentiation)

Example: 9186/3 Osteosarcoma/malign.

\section{Topography Codes of the Musculoskeletal System $[4,10]$}

- C40: Bone, joint and cartilage

C40.0: Upper extremity long bones, scapula, related joints, C40.1: Upper extremity short bones and joints 'thumb, wrist, hand'). C40.2 lower extremity long bones, 3: Lower extremity short bones.
- C49: Connective tissue (adipose, aponeurosis, vessels, fascia, fibrous tissue, ligaments, lymphatics, muscle, synovia, subcutaneous tissue, tendon) C49.1 Upper extremity, shoulder connective tissue C49.2 Lower extremity, hip connective tissue C49.5 Pelvis

\section{Morphology Codes of the Musculoskeletal System $[4,10]$}

- Soft tissue tumours

880 (sarcomas),

881-883 Fibromatous neoplasms 'e.g., fibrosarcoma, fibromatosis',

884 Myxomatous lesions,

885-888 Lipomatous lesions 'e.g., liposarcomas well differentiated, myxoid, round cell, pleomorphic, mixed, fibroblastic, differentiated,

889-892 Myomatous 'e.g.: Leiomyosarcomas'

904 Synovium,

912-916 Vessels 'e.g.: Angiosarcomas',

917 Lymphatics 'e.g.: Hemangiomas'.

- Bone-cartilage tumours (918-924).

Osteosarcoma: Chondroblastic, fibroblastic, telangiectatic,secondary to Paget disease, small cell, central, intraosseous-well differentiated, parosteal, periosteal, high grade superficial, intracortical.

Chondrosarcoma: Juxtacortical, myxoid, mesenchymal, clear cell, de-differentiated

- Giant cell tumours (925)

- Other bone tumours (926) 'e.g.: 9260/3 Ewing sarcoma'.

The alphabetic index is used to code both topography and morphology terms. It is located after topography and morphology indices. First stage is that the pathologist puts the relevant updated diagnosis and sends the diagnosis to the surgeon. Diagnosis, e.g., central osteosarcoma, could be further searched at alphabetic index depending on both the noun 'osteosarcoma' or the adjective 'central'. Possible morphology and topography codes are listed under the bold keyword. Further detailed topography or morphology codes can then be searched and found through the topography or morphology indices, and then the final 10 digit code can be reported.

Example: Pathology report: Humerus central osteosarcoma:

Alphabetic index:

O 'letter'

\section{Osteosarcoma}

9186/3 central (C40._C41._)

9186/3 central, conventional

9181/3 chondroblastic (C40.,,C41._) 
9182/3 fibroblastic (C40., C41._)

9184/3 in Paget disease, bone (C40._, C41._) Topography index:

C40.0 Long bones of upper limb, scapula and associated joints.

Acromioclavicular joint

Bone of arm

Bone of forearm

Bone of shoulder

Elbow joint

Humerus

Radius

Scapula

Shoulder girdle

Shoulder joint

Ulna

Final code is $9186 / 3$ (C.40.0).

\section{Orthopaedic Tumors Update at $3^{\text {rd }}$ Edition First Revision of ICD-O}

While all topography or localization codes remain the same as in the previous second edition, morphology or histopathology codes have been thoroughly reviewed and, where necessary, revised to increase their diagnostic precision and prognostic value due to recent cellular and genetic studies. $[4,10]$ Updates and differences between second editions are present in Tables 1-4.

\section{Discussion}

All ICD codes, neoplasm classification are reviewed and updated regularly especially with major revisions at hematologic malignity. $3^{\text {rd }}$ edition first revision especially clarifies the distinction between lymphoma and leukaemia. Cell origin determining studies was a revolution at this stage, both established the basic of this coding system differing it from previous old classification systems which were dependent on epidemiologic or clinical studies, increasing diagnostic accuracy of the tumours. Cytogenetic, molecular studies have a critical role at this process, as new subclassification of tumours are made; however, this is still at development or infancy stage. ICD-O $3^{\text {rd }}$ edition first revision differs from second edition incorporating tumour cell origin studies. $[4,10]$

Cancer registry centres and health statistics must depend on true data driven from true diagnosis. These codes and/or pathologic diagnosis are updated regularly dependent on recent immune-histopathologic, genetic studies. Thus, this coding system, common language worldwide, the sign of scientific development, enables clinicians to detect cancer early and true diagnosis.
Table 1 New codes in ICD-O third edition. The following 4-digit morphology code did not exist in ICD-O $2^{\text {nd }}$ edition[3]

9186/3 Central osteosarcoma (C40-, C41-) Conventional central osteosarcoma (C40-, C41-) Medullary osteosarcoma (C40-,C41-)

9187/3 Intra-osseous well-differentiated osteosarcoma (C40-,C41-)

Intra-osseous low-grade osteosarcoma (C40-, C41-)

9193/3 Periosteal osteosarcoma (C40-,C41-)

9194/3 High-grade surface osteosarcoma (C40-, C41-)

9195/3 Intra-cortical osteosarcoma (C40-, C41-)

9242/3 Clear cell chondrosarcoma (C40-, C41-)

9243/3 De-differentiated chondrosarcoma (C40-, C41-)

Table 2 New morphology terms and synonyms in ICD$\mathrm{O} 3^{\text {rd }}$ edition (The following 4-digit morphology codes existed in ICD-O, second edition)[3]

Table 3 Terms that changed morphology codes in ICD-O $3^{\text {rd }}$ edition[3]

\begin{tabular}{llc}
$\begin{array}{l}\text { ICD-O, second } \\
\text { edition }\end{array}$ & $\begin{array}{l}\text { Term as it appears } \\
\text { in ICD-O, third edition }\end{array}$ & Third edition \\
\hline $9190 / 3$ & $\begin{array}{l}\text { Parosteal osteosarcoma } \\
\text { (C40,C41) }\end{array}$ & $9192 / 3$ \\
$9190 / 3$ & $\begin{array}{l}\text { Juxtacortical osteosarcoma } \\
\text { (C40,C41-) }\end{array}$ & $9192 / 3$ \\
$9190 / 3$ & $\begin{array}{l}\text { Periosteal osteosarcoma } \\
\text { (C40,C41) }\end{array}$ & $9193 / 3$ \\
\hline
\end{tabular}

Table 4 Lesions that changed behaviour code[3]

\section{True neoplasm instead of} tumor-like lesion ICD-O, third edition

Giant cell tumor of the tendon sheath $9252 / 0$

Histiocytosis X $9751 / 1$

Eosinophilic granuloma $9752 / 1$

Hand-Schuller-Christian disease

$9753 / 1$

Benign instead of borderline malign

Desmoplastic fibroma

$8823 / 0$

Mature teratoma $9080 / 0$

Clinicians and pathologists must share this common language to build the true cancer data registry. The first step is true pathology diagnosis dependent 
on this updated system incorporating recent diagnostic terms and cancer types and then reporting this as a pathology result, in this well-known and worldwide shared coding system to the treating surgeon or oncologist then starting appropriate treatment and this team (pathologist and oncologist or surgeon) will then report this case at this particular system to build up national or international database. The recent studies still show inconsistencies between sarcoma codes reported by the treating surgeon and pathology reports. That only $61.8 \%$ of the cases were correctly coded by ICD-9 and ICD- 10 codes and $59.8 \%$ of cases were correctly coded by ICD-O-3. By subspecialty, only $72 \%$ of orthopaedic oncology codes were coded accurately. Most wrong coding's were made due to organ site rather than type of malignancy (e.g., gastric cancer instead of gastric gastrointestinal stromal tumour).[11]

Japan registry, one of the biggest cancer registries in the world, depending on ICD-O codes, reported chondrogenic tumours, especially the osteochondromas, as the most common benign bone tumour, peaking in 10-19 years of age. The most common malignant bone tumour was osteogenic tumours, in long bones of the lower limb at teenagers, the second was chondrogenic tumours. They cited giant cell tumours as intermediate tumours peaking at 20-29 years of age.[12]

This was similar for Turkey in that regional prevalence studies also pointed out cartilaginous tumours as number one for benign bone tumour while osteosarcoma for malign tumours.[13,14]

Being one of the oldest tumour registry, build in 1958, depending on ICD codes, the Swedish registry also pointed out diagnostic differences from time to time that from 1958 to 1982 ratio of malignant to benign giant cell dropped from 1.3 to 0.09 , probably due to failure of distinguishing giant cell containing osteosarcomas with malignant giant cell tumours. [15]

One of the most useful advantages of using the ICD-O coding system and keeping pathologists and treating physicians updated about the most recent information present at the regularly updated ICD-O coding system is giving countries a chance to build their own tumour registries. Like the above mentioned epidemiological studies performed in developed countries dependent on their national tumour registry by the usage of ICD-O coding system they must also be built and started to be used at developing countries later that would let them be able to talk the international language.

National tumour registries have to be built up that are dependent on data driven from worldwide accepted, regularly updated coding system and coded together by teams at least consisting of treating clinician and pathologist.

\section{Conclusion}

At the most recent edition of ICD-O third editon first revision (Fig. 1) in the light of most recent studies reporting new histopathologic markers, genetic information and the general updating of our cancer biology knowledge; new codes and pathologic codes have arisen or some have been deleted due to our more accurate understanding of morphology, the behaviour of tumours or tumour-like lesions.

This coding system not only enables us to share the common language among clinicians and researchers, also permits us to build national cancer data, with the new codes and diagnostic terms introduced being also important in influencing patient's treatment and prognosis.

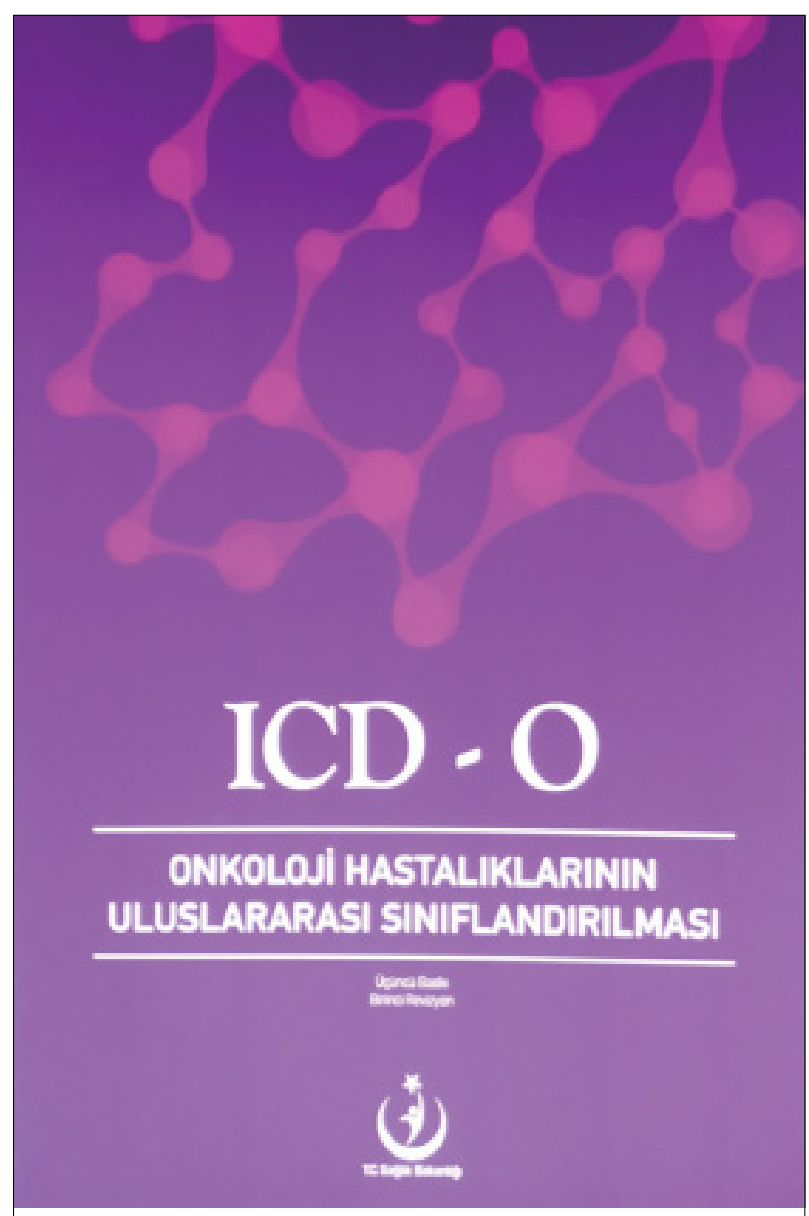

Fig. 1. Canda MŞ. Turkish version of ICD-O third editon first revision (ICD-O 3.1). Turkish Ministry of Health, publication number: 1071. Ankara, 2018. (10). ISBN: 978-975-590-669-0. 
Peer-review: Externally peer-reviewed.

Conflict of Interest: Authors declare no conflict of interest.

Financial Support: No financial support has been used for this study.

\section{References}

1. Graepel P, Henson DE, Percy LC, Thomas LB. International classification of diseases for oncology. $1^{\text {st }}$ ed. Geneva: WHO; 1976.

2. Pecy C, Von Holten V, Muir C. International classification of diseases for oncology. $2^{\text {nd }}$ ed. Geneva: WHO; 1990.

3. Fritz A, Percy C, Jack A, Sobin L, Parkin DM, Whelan S. International classification of diseases for oncology. $3^{\text {rd }}$ ed. Geneva: WHO; 2000.

4. Fritz A, Percy C, Jack A, Shanmugartnam K, Sobin L, Parkin DM, et al. International classification of diseases for oncology. $3^{\text {rd }}$ ed, $1^{\text {st }}$ revision. Geneva: WHO; 2013.

5. Fidaner C, Eser SY, Parkin DM. Incidence in Izmir in 1993-1994: First results from Izmir Cancer Registry. Eur J Cancer 2001;37(1):83-92.

6. Eser S, Zorlu F, Divtik RT, Çal Ç, Ozkan M, Kirkali Z. Incidence and epidemiological features of cancers of the genitourinary tract in Izmir between 1993-2002. Asian Pac J Cancer Prev 2009;10(3):491-6.

7. Canda MS. New histopathological diagnostic terms and their codes of the central nervous system (CNS) in the international classification of diseases for oncology (ICD-O 3.1) and about the Turkish version of ICD-O. J Cancer Diagn 2017;2(112):2253-476.

8. Canda MŞ. Turkish version of ICD-O $2^{\text {nd }}$ ed. (In: Pecy C, Von Holten V, Muir C, editors. International classification of diseases for oncology. $2^{\text {nd }}$ ed. Geneva:
WHO; 1990). Ege Üniversitesi Kanserle Savaş ve Uygulama Merkezi yayını, N0: 1. İzmir: Ege Üniversitesi Basımevi; 1992.

9. Canda MŞ. Turkish Version of ICD-O $3^{\text {rd }}$ ed. (In: Fritz A, Percy C, Jack A, Sobin L, Parkin DM, Whelan S, editors. International classification of diseases for oncology. $3^{\text {rd }}$ ed. Geneva: WHO; 2000). Ekopatoloji derneği yayını. İzmir: META Basımevi; 2002.

10. Canda MŞ. Turkish Version of ICD-O $3^{\text {rd }}$ ed, $1^{\text {st }}$ revision. (In: Fritz A, Percy C, Jack A, Shanmugartnam K, Sobin L, Parkin DM, Whelan S, editors. International classification of diseases for oncology. $3^{\text {rd }} \mathrm{ed}, 1^{\text {st }}$ revision. Geneva: WHO; 2013). Türkiye Cumhuriyeti Sağlık Bakanlığı yayını, N0: 1071. Ankara: Kuban Basımevi; 2018.

11. Lyu HG, Stein LA, Saadat L V, Phicil SN, Haider A, Raut CP. Assessment of the accuracy of disease coding among patients diagnosed with sarcoma. JAMA Oncol 2018;4(9):1293-5.

12. Sugiyama H, Omonishi K, Yonehara S, Ozasa K, Kajihara $\mathrm{H}$, Tsuya $\mathrm{T}$, et al. Characteristics of benign and malignant bone tumors registered in the Hiroshima Tumor Tissue Registry, 1973-2012. JB JS Open Access 2018;3(2):e0064.

13. Yücetürk G, Sabah D, Keçeci B, Kara AD, Yalçinkaya S. Prevalence of bone and soft tissue tumors. Acta Orthop Traumatol Turc 2011;45(3):135-43.

14. Dabak N, Cıraklı A, Gülman B, Selçuk MB, Barış S. Distribution and evaluation of bone and soft tissue tumors in the middle Black Sea Region. Acta Orthop Traumatol Turc 2014;48(1):17-24.

15. Rockberg J, Bach BA, Amelio J, Hernandez RK, Sobocki P, Engellau J, et al. Incidence trends in the diagnosis of giant cell tumor of bone in Sweden since 1958. J Bone Joint Surg Am 2015;97(21):1756-66. 